\title{
Why Jus Cogens: Why a New Journal?
}

\section{Claudio Corradetti ${ }^{1} \cdot$ Mattias Kumm ${ }^{2,3}$}

Published online: 24 May 2019

(C) Springer Nature Switzerland AG 2019

There is a remarkably new event to the attention of international legal and philosophical scholarship. During its sixty-seventh session in 2015, the International Law Commission (ILC) decided to invest its next long-term work programme in defining the notion of jus cogens and more in general the idea of 'peremptory norms of general international law'. This noteworthy fact embodies potential systemic effects on various areas of law and philosophy, as with regard to the challenge of placing the legitimacy of international politics beyond the contractual power of the states.

Such groundbreaking event is at the forefront also of the research ambitions of this journal. Jus Cogens journal aims at promoting new conceptual research and throughout discussion for the clarification of the potentials of innovation in philosophy law and politics. Jus cogens as a conceptual category, though, is an old source of international law and reflection upon international justice. The notion was part of a legal framework since the time of Roman law, with the division in the Digest between jus cogens (peremptory law) and jus dispositivum (contractual law brought about by 'will' of the power-entities). The distinction was at the core of the development of cosmopolitanism in international law through a transferring of the Stoic notion of rationality (logos) into a legal framework. Through the works of Grotius, Vattel, Wolff, Rousseau, and finally Kant, an earlier conceptualization of modern jus cogens took the form of cosmopolitan right.

In particular, Kant's Doctrine of Right and his seminal text on Perpetual Peace testified to the strict interrelation between a scheme of justice and a coercive law. ${ }^{1}$ Recent trends in

\footnotetext{
${ }^{1}$ Cfr. Kant (1999a, b), 311-352, 353-604. On the constructivist interpretation of Kant see Corradetti (2017), 'Constructivism in Cosmopolitan Law: Kant's Right to Visit',Global Constitutionalism, 6(3), 412-441. On the translation of 'Recht' with 'justice', see Pogge (1988)n.d., 'Kant's Theory of Justice', Kant Studien, 79(1-4), $407-433$.
}

Claudio Corradetti

Claudio.Corradetti@uniroma2.it

\footnotetext{
1 University of Rome Tor Vergata, Rome, Italy

2 New York University, New York, NY, USA

3 Humboldt University, Berlin, Germany
} 
philosophical investigation and legal positivism have tended, instead, to separate such two spheres and regarding them as self-sustained and enclosed domains. ${ }^{2}$ This view is now up to challenge. In the last few decades, academics and international legal practitioners have increasingly contributed to identify and account for the role of general principles as legal concepts in compliance with moral and constitutional standards, both within the domestic and the global setting. ${ }^{3}$

So what is jus cogens today? How can it be fruitfully conceptualized?

While the concept has been compared to a trump card left unused, after a legal recognition by states with the Vienna Convention for the Law of Treatises (adopted in 1980), jus cogens has acquired the potential for redefining the fundamental criteria of law's validity and its practical effects on states, moving away from a purely positivist view. Advancement in research has been sought through investigation on the potential that jus cogens has also displayed for the reshaping of several areas of international law and state practice, such as human rights law, international humanitarian law, the law of international responsibility and so on. An enhanced understanding and application of this concept today can provide international judiciaries and institutions with the delivery of higher standards of justice. Due to the values involved, the definition and tracking of jus cogens norms require an integrated legal and philosophical research method for the clarification of notions as those of 'community interests', 'sacred trust of civilization', 'human dignity' and so on.

These categories, when applied to legal reasoning, cut across the long-winded debate between natural law thinkers and legal positivists. This looks as a telluric shift. Indeed, it opens a new phase after the idea of natural law as jus gentium faded away, by the end of the nineteenth century, and after state consent became in the twentieth century an essential component of the positivist turn of international law. ${ }^{4}$

D. Lanzillotti was the first to conceptualize this aspect for customary law in the judgment of the SS Lotus Case. ${ }^{5}$ Opinio juris was seen, there, as only requiring individual consent by the states, even if much later, in the Diallo Case, the Court affirmed that mere practice was not enough. ${ }^{6}$

Yet, besides these historical reconstructions, jus cogens is relevant today because it conveys the idea of what is ultimately important for a theoretically engaged reflection upon law and politics. It also shows how the legal and the practical domains, when taken together, behave as inherently co-dependent variables.

Indeed, one might argue that, in issues pertaining jus cogens, the definition of opinio juris necessitates to resort to moral and evaluative elements still currently under-investigated. How

\footnotetext{
2 'Law is, indeed, no longer presumed to be an eternal or absolute category... The idea of an absolute legal value, however, is not quite lost but lives on in the ethical notion of justice which positivist jurisprudence continues to cling... The science of law is not yet wholly positivistic, though predominantly so (emphasis added)', in H. Kelsen (1934), 483-484.

${ }^{3}$ See for the domestic side R. Dworkin (1977); R. Alexy (2010); R. Bellamy (2009). For some of the most influential theories on global cosmopolitanism, see M. Kumm (2009); N. Walker (2008), 519-543.

${ }^{4}$ For a philosophical engaged perspective on the matter, from the perspective of a contemporary natural law thinker, see J. Finnis (2012), 238-245.

5 "Il y a accord tacite lorsque la volonté des Etats de s'engager à observer réciproquement une conduit donnée résulte des faits. Lorsque cette volonté se manifeste par la constant repetition d'une manière donnée d'agir dans des circostances données, on parle plus proprement de coutume (tacitum pactum): règle observée en fait avec la conviction d'observer une norme juridique", in, D. Anzillotti (1929), 73.

${ }^{6}$ Ahmadou Sadio Diallo (Republic of Guinea v Democratic Republic of the Congo, 2007, ICJ).
} 
to move from a false conscience of a presumptive duty for states to the true conscience of a requirement of jus cogens? ${ }^{7}$

Concerning jus cogens obligations, these appear to be linked directly to the search for fundamental values in the international law community. However, here, the onus of proof falls on the ultimate values upon which the international community grounds membership. Therefore, engagement in practical reasoning is essential for solving the inconsistencies between de facto validity and de jure rejectable agreements - a separation replicated at the law level by the distinction between lege ferenda and lege lata.

There are certainly methodological assumptions that help in redefining the framework of international law and justice. The intellectual ambition of this journal is precisely to prompt the renewal of a philosophical agenda through the support of an interdisciplinary methodology.

Among other things, this means to reconsider new routes for what John Rawls, for instance, called the ideal of a 'realistic utopia' ${ }^{8}$ The suggestion here made is therefore one oriented to the construction of new normative planes. In this respect, the standards provided by a notion of jus cogens make clear that all states live under the roof of a common legal order which holds them firm to inescapable obligations, regardless of whether they act individually or collectively. As it goes uncontested that bilateral obligations in multilateral treaties do not exempt third-party states from interest to compliance (even if this does not establish a duty), jus cogens adds a deeper level of inderogable obligations whose interest in compliance applies to all. Thus, the prominence of jus cogens emerges in all its potential in the redefinition of multilateralism through the introduction of obligations for all states (so-called erga omnes obligations). Not surprisingly, therefore, the idea of legitimate authority comes to depend on the satisfaction of certain constraints that the notion of jus cogens captures, as with its emphasis on the primacy of law as a theoretical framework of justification. But here, the ordering of concepts for a justificatory practice becomes all important, affecting profoundly also the way in which methodologies are constructed. Indeed, before anything else, it is up to the principles of reason to display ultimate standards of justification over the legitimation of institutional configurations or political practices.

An asymmetry arises in the relation between law and politics, that is, between the philosophical component of the law and the political dimension embedded within. As it appears, such asymmetric relation concerns the notions of freedom and morality. This opens to a host of very complex issues that are still waiting to be clarified. The relation between law and politics remains one between a virtual ideal system of freedoms and obligations, on the one side, and one of a non-ideal, but hopefully freedom-approximating process, on the other side.

Philosophical reflection is necessary for the reconstruction of the ideal conditions of coercive justice, but it is only through the practical exercise of political wisdom that such an ideal can be brought into effects by means of a public and discursive rationality. Contestatory views become part of this game in so far as they show a similar pre-commitment to justificatory strategies. What does not enter into the discussion, though, is a bowing and complacent attitude to all those non-critically checked views ultimately hiding forms of philosophical authoritarianism. The intellectual dimension here defended, therefore, is one which ultimately connects the philosophical understanding of our institutional world to the normative and emancipatory force of rights through specific political practices. Under such

\footnotetext{
7 J. Crawford (2014), $67 \mathrm{ff}$.

${ }^{8}$ J. Rawls (2001).
} 
premises, a divide between analytic and continental traditions does not appear to carry any meaningful significance. Contrariwise, both the consideration of philosophical clarity and conceptual distinctions, as well as the faithfulness to the original purpose of philosophical enquiry, are considered together under a Socratic blessing.

Our political and legal world is changing profoundly. Yet, the inspirational guidance under which falls the illustration of this new journal reflects the conviction that no theory without practice can provide intellectual guidance, and that such separation paves ultimately the way to the unacceptable scission of unimaginative and ineffectual thinking.

Is it not the case that the technicization of the intellectual life has come close to the managerialization of the intellectual profession? Cultural entrepreneurship seems to be the result of such evil kiss. We cannot take this as a satisfactory result.

The critical approach promoted by this journal dismisses therefore an attitude of intellectual blindness due to the bureaucratization of the intellectual life. It rejects also those ideological filters impeding the pursuance of honest reflection. This orientation in thinking is the only guarantee for avoiding a condition of self-incurred minority, as Kant had prefigured. In the attempt to define a new research agenda dodging the gambling away of fundamental values and cognizant of the several options at hand in legitimate redistributions of goods and services, the Jus Cogens journal wants to stand as a counter-choir to facts-independent mainstream narratives. Accordingly, theoretically driven analyses on practical-legal effects are mostly welcome, together with philosophical reflections illuminating social practices. As the journal subtitle points out, doctrinal aspects of law or political institutional practices are welcomed in so far as they incorporate critically informed standards.

These are certainly challenges that cannot be avoided if we do not want to miss the opportunity to trace peaceful alternatives to the unfolding of our future prospects.

\section{References}

Alexy R (2010) A theory of constitutional rights. Oxford University Press, Oxford

Anzillotti D (1929) Cours de droit international public. Recueil Sirey, Paris, p 73

Bellamy R (2009) Political constitutionalism, a republican defense of the constitutionality of democracy. Cambridge University Press, Cambridge

Corradetti C (2017) Constructivism in cosmopolitan law: Kant's right to visit. Global Constitutionalism 6(3):412441

Crawford J (2014) Chance, order, change: the course of international law, general course on public international law. Brill, Nijhoff $67 \mathrm{ff}$

Dworkin R (1977) Taking rights seriously. Harvard University Press, Boston

Finnis J (2012) Natural law and natural rights. Oxford University Press, Oxford, pp 238-245

Kant (1999a) Toward perpetual peace. In: Gregor M (ed) Immanuel Kant: practical philosophy. Cambridge University Press, Cambridge, pp 311-352

Kant (1999b) The metaphysics of morals. In: Gregor M (ed) Immanuel Kant: practical philosophy. Cambridge University Press, Cambridge, pp 353-604

Kelsen H (1934) The pure theory of law: its method and fundamental concepts, tran. By C.H. Wilson in (1934) 50 The Law Quarterly Review 474:483-484

Kumm M (2009) The cosmopolitan turn in constitutionalism: on the relationship of constitutionalism in and beyond the State. In: Dunoff JL, Trachtman JP (eds) Ruling the world? Constitutionalism, international law and global governance. Cambridge University Press, Cambridge

Pogge T (n.d.) Kant's theory of justice. Kant-Studien 79(1-4):407-433

Rawls J (2001) The law of peoples. With 'the idea of public reason revisited. Harvard University Press, Boston

Walker N (2008) Taking constitutionalism beyond the State. Pol Stud 56(3):519-543 